\title{
AN INNOVATIVE MODEL FOR THE ADMISSION OF TALENTED HIGH SCHOOL STUDENTS TO THE UNIVERSITY: A CASE STUDY
}

\author{
Kamil Arif KIRKIÇ ${ }^{1 *}$, Kadriye GÜRDAĞ ${ }^{2}$, Emin AYDIN ${ }^{3}$ \\ ${ }^{1}$ Asst. Prof. Dr., Istanbul Sabahattin Zaim Üniversity, Turkey, kamil.kirkic@izu.edu.tr \\ ${ }^{2}$ Graduate Student, Istanbul Sabahattin Zaim Üniversity, Turkey, kadriyegurdag@gmail.com \\ ${ }^{3}$ Prof.Dr., Marmara University, Istanbul, aydin@marmara.edu.tr \\ ${ }^{*}$ Corresponding Author
}

\begin{abstract}
The education of gifted students differentiates from regular education based on their status. Special education for talented individuals in Turkey has a variety of applications starting from elementary schoolage.. Although they receive different pieces of training, there are no transition processes similar to the differentiated practices provided in their education to move to a higher education institution. 983,000 12thgrade students have taken the university entrance exams in 2019. Assuming that $3 \%$ of the students who took the exam were gifted, approximately 30,000 gifted students have taken this exam. In line with the model recommended by Kırkıç for gifted students, the use of a different model in transition to university should be considered for gifted students. This study was carried out with a qualitative single case pattern, the purpose of which was to determine the participant's opinions about the summer school application, which can be used for the transition of gifted high school students to universities, which are higher education institutions. Participants of the study are a student who studies at the summer school determined by the purposeful sampling method and the supervisor of the laboratory in which she studies. In this study, it was aimed to evaluate the laboratory studies process and the summer school application proposed by the model, where gifted high school student voluntarily attends during the summer holiday of the year she passed the 10th grade. Also, the opinions of the supervisor of the laboratory studies attended by the student were taken. Data were collected through interviews, observation, and renegotiation. Interview voice recordings were obtained with the permission of the participants. A descriptive analysis was done after obtaining the data. According to the results of the analysis, it was found that the activities performed by the gifted high school students in summer school based on their interests help them to decide their department after the university exam, increase their motivation, provide learning experience by doing and living, contribute to deep learning, create the opportunity to experience university life, and make them aware of the advantages and disadvantages of starting early. According to the results of the analysis, it was found that the activities performed by the gifted high school students in summer school based on their interests help them to decide their department after the university exam, increase their motivation, provide learning experience by doing and living, contribute to deep learning, create the opportunity to experience university life, and make them aware of the advantages and disadvantages of starting early.
\end{abstract}

Keywords: Gifted high-school students, Transition to university, Innovative transition model to university 


\section{INTRODUCTION}

The admission of high school students to the universities in Turkey is carried out by a central examination. Republic of Turkey Measurement Selection and Placement Center (MSPC,[ÖSYM]) exams required for admission to universities have been organized since 1974 (ÖSYM, 2019). Performing both the selection and placement functions of high school students, ÖSYM also conducts many central exams apart from these. However, these exams are generally applied to high school students, and there isn't a not different exam for special talented students. Talented students, regardless of how different their education is and in which field their special talents are, have to take these exams to start university.

The education of gifted students differentiates from regular education based on their status. Special education for talented individuals in Turkey has a variety of applications starting from elementary school-age. Although they receive different pieces of training, there are no transition processes similar to the differentiated practices provided in their education to move to a higher education institution. According to the data from MSPC, 983,000 12th grade students have taken the university entrance exams in 2019. (ÖSYM, 2019). Assuming that $3 \%$ of the students who took the exam are talented, approximately 30,000 talented students have taken this exam. In line with the model proposed by Kırkıç (2019) for special talented students, it should be considered to use a different model for students with a special talent in the transition to University.

This study was carried out with a qualitative single-case pattern, the purpose of which was to determine the participant's opinions about the summer school application, which can be used for the transition of special education students to universities. Participants of the study are a student who studies at the summer school determined by the purposeful sampling method and the supervisor of the laboratory in which she studies. In this study, it was aimed to evaluate the laboratory studies process and the summer school application proposed by the model, where a gifted high school student voluntarily attends during the summer holiday of the year she passed the 10th grade. Also, the opinions of the supervisor of the laboratory studies attended by the student were taken. Data were collected by interviews, observation, and renegotiation. Interview voice recordings were obtained with the permission of the participants. After obtaining the data, descriptive analysis was made. According to the results of the analysis, it was found that the activities performed by the gifted high school students in summer school based on their interests help them to decide their department after the university exam, increase their motivation, provide learning experience by doing and living, contribute to deep learning, create the opportunity to experience university life, and make them aware of the advantages and disadvantages of starting early.

\section{SPECIAL TALENT CONCEPT}

The issue of how to address individuals who have special qualities is a subject of discussion. The First National Congress for Gifted Children was held in 2004 in Turkey. The general trend in Congress has been to use the term "gifted". The World Council prefers the term "gifted and talented" (Kaplan, 2008). In addition to these, the term "gifted individuals" is recognized worldwide, while different researchers in the field were observed to use the terms "high-potential individuals" and "gifted individuals"; though in Ministry of National Education (MEB) publications, the term "gifted individuals" is used and is becoming widespread. In the publication titled "Understand Me: I Have a Specially Talented Child" prepared by the Ministry of National Education, General Directorate of Special Education Guidance Services (ORGM), a specially talented individual is defined as follows: "a talented individual is one who learns faster than his/her peers; has high capacity for creativity, art and leadership, possesses special academic ability, understands abstract ideas, loves to act independently in areas of interest and performs at a high level" (MEB, 2017).

According to the Marland Report published in America, where research on giftedness was carried out intensely starting in the 1950s, gifted and gifted/talented individuals are defined as as individuals who need differentiated education programs and services beyond normal school programs determined by professionals qualified in this field in order to contribute to themselves and the society (Marland, 1972). In this context, it can be said that providing access to the differentiated education programs and services needed by gifted and talented students is among the holy duties of program developers and educators. By adopting these duties as principles, productive outputs can be obtained from educational processes by utilizing educational programs and models designed according to the needs of the gifted and talented individuals, who are spiritual treasures of the society. This way, they can be provided with the quality education they need.

\section{MODELS USED IN EDUCATION OF SPECIAL SKILLS}

Basic strategies used in the education of special talented individuals are termed acceleration, enrichment, 
and grouping (Şahin \& Levent, 2015). The education programs in the curriculum should be differentiated with strategies such as acceleration, enrichment, and grouping for the students with special abilities to benefit from the educational processes in the most efficient way. Quality education, which appeals to the needs of specially talented students and satisfies the information hunger they experience intensely, is provided only through differentiation.

\subsection{Differentiation}

The differentiation of the education program is, by definition, the arrangement of the program by the individual differences and needs of the students in the classroom and making the education suitable for this (Kanlı, 2011). In other words, differentiation is the planning of the program from the beginning by the characteristics of specially talented students such as faster learning, better problem solving, abstract thinking, and establishing relationships between concepts (Akkaş \& Tortop, 2015). According to the article 22 of the "17th National Education Council Resolutions", "gifted children should be provided with the opportunity to progress at their own pace" (MoNE, 2006), the most basic way for gifted individuals to be able to receive the education they need and to progress at their own pace is to provide education with differentiated programs beyond the ones prepared for students of normal intelligence.

Contrary to the opinions of anti-elitists, who question the necessity of differentiated programs, providing differentiated education to talented students does not mean creating an "elite group", and ensuring that these students receive education suited to their characteristics is a requirement of democratic and social state mentality (Levent, 2011).

\subsection{Acceleration}

Acceleration is an intervention that supports permanent and effective learning in the education of special talent and eliminates the obligation of listening to what the gifted individual already knows, which they encounter frequently in the academic life. It yields highly effective results. Acceleration of teaching means that students are subjected to a more advanced education program than the normal education program, which brings more complex information to the student and intensifies the material to be learned. The learning materials used in the differentiated education in which acceleration is realized are explained faster than in a typical classroom and students take part in more challenging activities by taking education beyond the education of their peer groups (Kanlı, 2011). Because the enthusiasm of talented students ends in learning environments that are not challenging enough (MEB, 2014), it can be said that challenging education programs differentiated by acceleration strategies will be more beneficial for these students.

Acceleration interventions can be implemented in a variety of ways, such as early start to the first grade, skipping grades or courses, taking some courses from the university in high school, and compressing the content covered in three years into two years (mainly in mathematics classes) (Aydın \& Özdemir, 2020; Davaslıgil, 2004). For the education programs to differentiate, the most appropriate acceleration intervention is selected and applied by considering factors such as the stage of education, duration, student's needs, and the content of the program.

\subsection{Enrichment}

Enrichment strategies include independent study and research projects, excursions that will introduce them to fields based on culture and science or professional opportunities, Saturday programs, learning centers created in the classroom or school's resource room, creating moot courts and judicial tournaments for law and politics and Summer programs in communication arts, mathematics science, social sciences, visual arts, music, drawing, management, leadership, theater, dance, foreign language, psychology, solar system, computer, etc. (Davaslıgil, 1995). The summer programs to be held may differ depending on the interests and participation of the students, or they may differ according to the requirements of the current period. For example, considering the conditions of the time we are in, programs that will provide students with critical thinking and problem-solving skills, which are among the 21 st-century skills, can be made, as well as enriching education in summer programs with basic coding skills to train future engineers.

\subsection{Grouping}

Grouping applications include cluster groupings for specially talented students in normal classes, grouping with a special class, grouping in a private school, grouping in the resource room and grouping in resource centers, private seminars, private summer courses, and special studies in various study centers (museums, universities, science laboratories and industry etc.) (Ersoy and Avcı, 2004). 


\subsection{Grade Skipping}

The physical maturity, height, general emotional balances, motivations, and coping skills of the children to skip grades should be taken into consideration, and above all, it should be evaluated whether they need higher-level information (Davaslıgil, 1995).

\section{INNOVATIVE TRANSITION MODEL TO UNIVERSITIES}

The Korean Education Development Institute (KEDI), financed by the Korean government, has adopted the principle of developing students' abilities by conducting extra-curricular activities within its in-house special talented education centers. In Korean school systems where talented students can skip grades early or graduate from school early in the education process, high schools offer a 3-year education. In Korea, which has an advanced mentoring system, a high level of advanced guidance support is provided to guide gifted high school students to the university. Also, gifted students are provided advantages over others in admission to universities in the case they are interested in science. Apart from the central examination system, self-talented students have the opportunity to enter the best universities in the country with an interview system. Considering that the central examination system is a prerequisite for the universities in our country, the question of whether it is important to do science or to get a high score from an intensive memorizing examination comes to mind. In this context, if we note the absenteeism in $25 \%$ of special talented students who attend to Center of Science and Art (BILSEM) due to the fear of low scores in university exams, we can conclude that the inability of special talented students to spare time for science is directly proportional to their anxiety. This also correlates with the results of the research. The opinions about the kind of environment in which talented individuals should be educated include that there education should be coordinated with universities, and if necessary, the laboratories of universities should be used for the education of gifted and talented students. (TÜBITAK, 2010).

Gifted and talented children need an education model during which they can benefit from their talents and show themselves. If these requirements are not met, they will not have a chance to reveal their characteristics (Özbay, 2013). Steenbergen-Hu and Moon (2011) conducted a meta-analysis with the thirtyeight studies on acceleration between 1984 and 2008 and revealed that acceleration was effective on the academic achievement and socio-emotional development of specially talented students (Akt, Akar, 2015 ). Another way of acceleration is to take some courses from the university while studying in secondary education. For this to happen, the student spends part of the day at the university to take advanced classes, or if there are enough students to form a class in secondary school, the faculty member may personally teach at the high school. Thus, students can have some credits before starting university (Davasligil, 1995).

In the report of the collaboration conducted by The Scientific and Technological Research Council of Turkey (TÜBITAK), Turkish Management Sciences Institute (TÜSSIDE) and Ministry of National Education (MEB), one of the primary wishes of gifted students' parents is to make this transition to high schools and universities with a method different than the entrance exams (TÜBITAK, 2010 Gifted Education 20-22 December 2010 Common Mind Platform)

\section{THE AIM OF THE RESEARCH}

The study aims to determine the participants' opinions about the summer school application that can be used for the transition to universities. The problem of the study can expressed as "What are the opinions of the participants in the university summer school application proposed for the use of Special Talented High School Students for their transition to university?". The sub-problems for which answers are sought based on the main problem are:

1. What understandings arise in the student who participates in an applied education, which is considered as a summer school application?

2. Can summer schools designed for talented students by universities be used as an innovative method for the transition of special talented students to university?

\section{METHOD}

In this section, information about the model of the study, working group, data collection tools, and data analysis and validity and reliability features of the study are presented.

\subsection{Research Model}

This study is a case study, one of qualitative research design methods. The study was carried out with a 
single case pattern. Case study research to be a study of real life, a situation in the current context or environment (Yin, 2014). A case study can be defined as a process by which researchers describe the case with various sources of information about multiple cases from real-life or the creation of themes related to the case, as well as a process of description and thematization where information about a current case is collected (Creswell, 2014). In the case study, the analysis unit can be about more than one case or just one case. It is called a single or multiple case study. Intrinsic case study is another type besides single and multiple instrumental case studies, based on the purpose of case study. Case studies aiming to reveal a unique situation are called an intrinsic case studies, and case studies conducted to understand a specific subject are called instrumental case studies (Creswell, 2014).

This study was conducted to understand a single case of the summer school application on a gifted and highly successful student. Single instrumental case pattern was utilized for determining the opinions of the student and laboratory supervisor, who participated in the summer school laboratory practice, about the possible benefits of the summer school application proposed by Kırkıç (2019) for the transition of special talented students to the university.

\subsection{Study Group}

In qualitative studies, unlike quantitative researches, a sample determined within the scope of a purpose is subjected to in-depth examination. This sample can be very small or it can be a single case (Patton, 1990 act. Mertkan, 2015). Participants of the study are a student who studies in the summer school determined by the purposeful sampling method and the supervisor of the laboratory in which she studies. Although it is not exactly a summer school, this process was considered an opportunity for the student and the laboratory supervisor to evalute this process and the application of summer schools as the transition model for the gifted and successful students to the university without examination since the student has laboratory experience in the university environment.

The student participating in the study is a female student who has completed the 10th grade of a public high school, which accepts students with high scores in the high school entrance exam. The student was determined to have special talents when she started secondary school. The school, where she started to study at the secondary level, is a private school that also implements teaching programs for the specially talented. The student completed the first year of her three-year secondary school term in this school. Afterward, she completed the second and third classes of the secondary school in another private school, which provided a normal education. She also prepared for the high school entrance exam in this school. The student made observations and studies in the laboratory for two weeks and four days to observe and gain knowledge of the summer school laboratory practices in a foundation university. Although it is not a full summer school, the participants were chosen to be evaluated by Kırkıç (2019) as it was an application that can shed light on the model he proposed for the admission of talented students to the university without exams .

In the study, the instructer and supervisor of the laboratory who accepted the high school student to his laboratory within the framework of the summer practice is male researcher who has a Chemistry degree and works as a researcher. He has ten years of laboratory experience, and has been working for five years in the institution where the study took place. He also serves as an R\&D supervisor and a laboratory coordinator assistant in a halal food research center. He has published articles in the fields of Chemical and Food Engineering. As a TÜBITAK laboratory quality accreditation officer, he is a highly experienced researcher in laboratory accreditations. During the research, the researcher, who continued his master's degree in Pharmacy, completed his master's degree and got the title of expert.

\subsection{Data Collection and Data Collection Tools}

Data was collected through interview and observation methods. The opinions of the student and the laboratory supervisor who participated in the summer school laboratory application were taken through a semi-structured interview (interview). Voice recordings of the interviews were taken and then analyzed. Also, the observations of both researchers are the other data collection tool of the study. The data were analyzed by an integrated analysis of the overall situation.

\subsection{Validity and Reliability}

Providing validity in qualitative research is a feature that is difficult to achieve as high as reliability. In addition to semi-structured interviews on internal validity, the observations of the researchers and the laboratory supervisor supporting the research are the applications that were used to ensure the validity of the study at any time. The sample, environment, and processes for external validity are described in detail. Diversification 
can be seen as a problem since the diversification of the sample is a purposeful and easy sampling. The researchers who made more than one observation were also supported with the observations of the laboratory supervisor participating in the research (Yıldırım \& Şimşek, 2008). The sound recordings taken during the semi-structured interview were analyzed and the analysis results were shared with the participants, allowing them to confirm.

\subsection{Data Analysis}

The analysis of the data was carried out within the framework of the plan developed by the researchers. The data analysis utilized techniques including the three ways suggested by Walcott (1994): direct description of data, creation of themes from descriptions, and comments by the researchers taking the description and theme creatin phases into consideration. (as cited in Yıldırım \& Şimşek, 2008). In other words, qualitative data can be analyzed with descriptive analysis and content analysis proposed by Strauss and Corbin (1990) (as cited in Yıldırım \& Şimşek, 2008). According to Dey (1993), there are three main levels of analysis in qualitative data analysis, namely description, classification, and association. During descriptive analysis, it is an important process to identify and explain the possible features of the individual, case, and events in the study (Gürbüz \& Şahin, 2018). Descriptive analysis was used to analyze the data of this study. Because of the limited number of participants, only descriptive analysis was included due to the limitations of data collection diversity. Descriptive analysis was applied on the participants' answers and observations to the questions asked during the interview within the conceptual framework found in the model established by Kırkıç (2019).

\section{FINDINGS}

In this section, the findings of the descriptive analysis on the data obtained from semi-structured interviews and observations are presented. The findings obtained from the interview questions were obtained from the interview records of the participant student and the laboratory representative. Student (STU) and laboratory supervisor (LABS) were asked questions about summer school. First, the student's, and then laboratory supervisor's answers were presented as findings based on the questions.

\subsection{Findings from the Question "Should there be a different application for gifted and talented students in the transition from high school to university?"}

The participating student and laboratory supervisor have stated that there should be a different procedure for specially gifted and talented students in transition from high school to university.

STU: "It should be. Because sometimes high school can be a boring place. ......... Therefore, if gifted people were given such a chance, they could learn in a short time without getting bored, and I think that talented and gifted individuals lose their edge in the normal system."

LABS: "It could be, it should be. Again, these practices should be determined according to the students' skills. ...........For example, if the individual has talent for piano, bağlama or guitar I think the education should proceed according to these talents. "

\subsection{Findings from the Question "Is the four-year training period sufficient for university preparation?"}

The student, has stated that the four-year high school education period too much for the students with special talents. She stated that the guidance is more important than the duration of high school education. Laboratory supervisor emphasizes that the quality of education received during high school education is more important than the duration.

STU: I think four years of education is too much, sometimes you may not be able to decide what to do even if you take four years in high school. If people received guidance and support, and if there is a competition program, like a demo program by the university and you have the chance to see the universities, three years may be enough. We learn certain things for four years, but we still may not be able to decide. "

LABS: Now it is important for me how full these four years are, rather than this four years, three years, five years discussion. I mean, what is offered and what is expected during these four years, this is what matters to me. Rather than it being four years or three years, the education's content and its follow-up are important. "This student, whom we gave this four-year education, won the university, graduated, became an engineer in a factory or an analyst in a laboratory, what difficulties did she face, was the education sufficient or not?" I think there we need feedback and coordination in this regard. 


\subsection{Findings from the Question"How did a high school student's participation in the laboratory studies at the university summer school help the student "}

In the student's statement, it is mentioned that the laboratory studies conducted in the summer school contributed to her motivation and her awareness of the effects of applied education. The laboratory supervisor states that the lab studies helped broaden the student's horizon and provided scientific thinking skills.

STU: First of all, even breathing the university atmosphere can add something to you.. I think I learned new things in the laboratory environment. My school has a different environment than the laboratory. So it gave me different perspectives, I can say that I decided that this is what I love. It was a good experience for me to observe the students studying there. One wants to be like them. Because they are studying alone and they can research what they want. It is a beautiful thing. I saw that they do different studies, they are doing cancer research, for example, food students, food engineering students. These caught my attention and I wanted to be in their place, I wanted to be like them. It can be said that the thing that separates high school from the university is the conservative attitude of the teachers. For example, the other day we researched the proteins, we learned the theoretical information about the proteins. It would be better if we saw the theory and application parts of the proteins quickly ,in our school, , the information would become more permanent so we don't forget it quickly.

LABS: I think it allowed the student to open her horizons in the scientific sense. I think it will contribute to the development of thinking in different dimensions. I think she will be more interested in these subjects in university because she saw different, more advanced systems at the high school level."

\subsection{Findings from the Question "How can the popularization and systematization of summer schools at universities benefit high school students?"}

In the words of the student and the laboratory supervisor, it is stated that popularizing and systematizing summer schools will provide important benefits to the students. In addition, they will encourage the students to think broadly. This would help students make more accurate decisions in choosing their field.

STU: I think that it could help people in choosing a field and provide different perspectives, seeing things in application. When there is application, it also creates a sense of curiosity and you start to think more broadly.

LABS: I think it will greatly benefit. Because we have a highly imaginative society. In this sense, if the student groups come selectively, I underline this, it will provide great benefits. I don't know how to decide whether the student is gifted or not, but after this decision, if the individual is gifted, I think he/she should attend some classes in at least the first year of university. Because if the student is going to proceed in that area, let him/her breathe the atmosphere, see the environment and say "Yes, this is for me" and carry out activities to improve himself/herself in that area. ..............To see concrete data about benefits, we can request reports about what we provide, , a literature study about what we provide, or a compilation study about what we provide, see the cause and effect relationship; that way we can have data that is tangible and trackable.

Afterwards, when he/she asks us about the points he/she does not understand about the work done there; we can understand where the student is, to what point he/she has come, and what he/she has been up to. In this sense, I believe that we can reach many arguments, abstract and concrete, in very different ways."

\subsection{Findings from the Question "What kind of cooperation can be established between high schools and universities to provide more qualified education for gifted and talented students?"}

The student and the laboratory supervisor propose that coordinated efforts should be made to popularize summer schools and enable the students to see and experience the studies in universities at an earlier age.,

STU: Summer schools or universities may be good in this regard. Students can attend classes in any field they want. It is a good practice to open summer schools and receive guest students in their laboratories. Summer schools can also guide us on what to decide. For example, if I think about three different departments, I will attend the classes of these departments and see which one will be more suitable for me by seeing these classes."

LABS: I was a successful student eligible to skip from the third grade to the fifth grade. My family did not allow it because I was young and they thought I would be overwhelmed. My teacher requested it, but my parents did not allow it. I'm glad, I didn't have any trouble, so I don't know how it would be, but I think that we 
Proceedings of SOCIOINT 2020-7th International Conference on Education and Education of Social Sciences,

should be able to feed the minds and dreams of the gifted and talented children. After all, we cannot be enough for these people. I have my laboratory to train these students, there are even better laboratories than mine, in Istanbul, Ankara, and Izmir. Let me give the simplest; I studied on a mouse brain for advanced analysis by dissecting the brain to test a product of a brand working on drugs for Alzheimer's. Now if we show this to a gifted child, his horizons will broaden. Would he ever think that mice brain are studied on by dissection? Suppose he knows about it at that age. If he is interested in this direction, this person dreams of developing himself in that field. Supposing that the child is 14-15 years old, let's assume that he has 20 years ahead of him, the child who sees this at that age starts to do research on the subject and to scan the literature. You can't catch him after that point."

This is the first part, the second part is that it makes his dreams grow even more. This is how great honors such as Nobel Prizes are received in the world. From Aziz Sancar to Oktay Sinanoglu, all the great scientists receive their honors in this way. In addition to the Turkish people, we know that Einstein also showed extremely gifted characteristics at a young age. However, Einstein was thought to have a problem in his mind because superior intelligence was not recognized due to the conditions of his time and environment, or because he was not paid enough attention. I think that gifted people should be given special attention. In this way, I anticipate that the results will be very different."

\subsection{Findings from the Question "How do you see students finishing college at an early age? Do you think there may be adaptation problems regarding this issue? "}

The student and the laboratory supervisor think that starting the university at an early age is not a problem because of their superior success and giftedness. Also, it is stated that having a university education and graduation at an early age will not create any problems for the students in terms of adaptation.

STU: I think this depends on people. I believe that age will not be very important if the opinions are the same. Everyone can have older friends, so I don't think there will be a problem. Different age groups can also get along well with each other. When I look around, I have an older sister who goes to university. And I can speak comfortably with my sister's friends. I do not observe that the age difference is very problematic. Also, my older sister can have friends 3 years older or 4 years younger than herself. I don't think they have any age-related problems. So I don't believe my age will be a problem.

LABS: As someone who entered the university at the age of 16.5 , I can say that I experienced a somewhat similar situation. There are sometimes disadvantages when responsibility is imposed on people at a young age. But if we can turn it to an advantage, we can see the incredible effects of this situation. Take Oktay Sinanoğlu as an example, you can have the youngest professor in the world. But "how many are there?" this has to be questioned. I went and graduated at the age of 20-21, came from the military service at the age of 22, I have been working at the university for 10 years, but I already have worked at the pharmacy from the age of 12. So I have been working for 20 years. When I was 12 years old, I told myself I was going to be a chemist while preparing drugs for cancer patients in the pharmacy and after 10 years I became a chemist. Now I'm studying to be a M.Sc chemist. I continued with the doctorate. I have 20 years of chemistry adventure behind me. I studied lovingly and willingly, I did not want anything other than chemistry, all my university preferences were chemistry departments. There were a few departments other than chemistry that I wrote, but my scores weren't high enough for them anyway. 20 of my preferred schools were chemistry departments. This is the heart of the matter. It doesn't matter whether it's age 15 or 20. The important thing is to measure whether you can overcome the problem.

LABS: I don't think there is a big difference between university students and high school students. Because the people who came here also graduated from there, people who have already studied there. So I do not think there is a big difference between them, but I am in favor of choosing the students who will come here. In other words, if a student is not interested in molecular biology, chemistry, biochemistry, organic chemistry, food, nutrition, dietetics, there is no point in coming to such a laboratory. Or, if there is a big interest in sociocultural activities, there is no point in coming here. As I mentioned before, everyone has to have an idea to see places in fields that they love, want to deal with, do not get tired while studying, and enjoy."

\subsection{Findings from the Question "What can be the alternative of the current test system in transition to university?"}

The student and laboratory supervisor stated that gifted students can be offered different options in their transition to university due to their superior achievements and special talents. , .

STU: I am currently a student in the international baccalaureate program, and when this program is over, we 
Proceedings of SOCIOINT 2020- 7th International Conference on Education and Education of Social Sciences,

will receive a diploma after we have received a certain training. It makes sense to consider this document in the university admission system. Courses can be selected in this program. Depending on the interests of the students, for example, the student who wants to study economy can choose the department of economics and take different courses from there. I have chosen these fields because I like chemistry and biology fields, and you have two different level options in the international baccalaureate program in these fields. I chose high chemistry and high biology. I am now taking courses in those fields. As a result, I think it is a better program in terms of choosing courses because of the open-ended questions in international baccalaureate.

LABS: I think students should take an aptitude test. Students, should be taken in a three-month camp in a pool of universities after graduating from high school,. They should be asked what they want to study and in which field they want to progress in the lab, social centers, etc.. After that, appropriate studies should be made for one week, two weeks, or monthly, whichever is suitable, and then these studies should be measured with an exam. It should be seen what the person has done and learned in the past month. For example, 30 out of 50 people achieves very high scores, they should be trained in the areas they are interested and successful in, and they should be directed to those departments. I don't think the current system is adequate for this."

\subsection{Findings from the Question "Is there a system that you have seen in foreign countries that you can propose to implement in Turkey in terms of early admission of gifted and talented students to university?"}

The student and the laboratory supervisor suggest that gifted and talented high school students should be given access to more than one exam per year for admission to university; and that suitable practices in in the world that can be adapted to our country should be determined and implemented.

STU: I don't know how long the high school periods are in foreign countries. But I know that in high schools or at any level, there is a chance to take courses from upper classes, and in some countries, they have the right to take university exams in every class. In Turkey, the exam can only be taken in the senior year. I think it would be good if there were a chance to take the exam in the 11th class. I think it could have been better for people to try themselves during the 11th class. Because in our country, the university exam is held only once a year and that determines what you can do. I would like to have the chance to have multiple choices instead of one when choosing the university, and to be able to choose the best one.. It could be better if the exam was held twice a year. For example, there is the SAT program in the USA. It is one of the exams that can be taken when entering university, which happens twice a year. IB programs also hold exams in May and November. Those who do not succeed in May take the exam again in November. Also, I think we should know how to apply to the university with ourselves. "

$\angle A B S$ : If you want to be a society that will have a voice in the world, if you want to be a research-oriented society, if you want to catch the synergy that our ancestors achieved during their time, you have to give importance to fundamental sciences. There is no other way. Nothing can be good for a nation whose fundamental sciences and language are not strong. This is a question of chain. You will put your language, culture, customs, in the strongest link of the chain. On top of that, you will place courses in fundamental sciences such as physics, chemistry, biology, mathematics, and Turkish language. Then you will become an engineer, then you will become a doctor, then you will be a pharmacist.

You cannot be a very good pharmacist without knowing chemistry very well. You cannot be a very good doctor. Because; the doctor prescribes the medicine, the pharmacist sells medicine to the country. The pharmacist must know chemistry very well because the pharmacist is the person who makes the medicine. $A$ pharmacist is never trained to sell medicine in the world. Universities should take students with different options. I do not know worldwide practices in this regard, but it would be appropriate to examine and evaluate and adapt them to our country.

\section{CONCLUSION AND DISCUSSION}

It is considered necessary to implement different applications for gifted and talented students in the transition from high school to university. The four years of secondary education for gifted and talented students in Turkey are considered to be long. This period should be shorter for gifted and talented high school students. It would be appropriate to shorten the duration with a higher education quality rather than increasing the high school period.

Alternative models need to be created for the admission of gifted high school students to university. In this context, university entrance exams can be administered twice or three times a year instead of once a year. Summer schools organized by universities can be a good alternative. Studies in summer schools can 
increase the motivation of gifted and talented students and help making their university department choices more consistent. Starting university at an early age with alternative transition models is not considered as a problem by students. More than one university entrance exam can be arranged per year for the admission of successful and talented students to university. Also, the applications from the world can be adapted and implemented.

\section{SUGGESTIONS}

Conducting this study with more high school students will help obtain more detailed information. Also, conducting researches using a mixed-method instead of a qualitative research model will provide results that can be evaluated from different aspects.

During the process of admission to university from high school, prospective models for successful and talented students should be taken under scope and studied. It is very important for the gifted students and the future of the country that Making the potential of gifted and talented students benefit the society after a shorter education process is very important for these students and the future of the country.

\section{REFERENCE LIST}

Akar, İ. (2015). Üstün Yetenekli Öğrencileri Genel Eğitim Sınıfında Destekleyecek Sınıf Öğretmeninin Sahip Olması Gereken Yeterlikler. Doktora Tezi. Hacettepe Üniversitesi.

Akkaş, E , Tortop, H . (2015). Üstün Yetenekliler Eğitiminde Farklılaştırma: Temel Kavramlar, Modellerin Karşılaştırılması ve Öneriler. Journal of Gifted Education and Creativity , 2 (2) , 31-44

Aydın, E. \& Özdemir; A. (2020). Matematikte Üstün Yetenekli Öğrenciler için Etkinlik Kavrami. Matematik Eğitiminde Etkinlikler ve Sinif İçi Uygulamalari. Anı Yayıncılık.(In Print)

Creswell, J. W. (2014). Research Design: Qualitative, Quantitative and Mixed Methods Approaches (4th ed.). Thousand Oaks, CA: Sage

Davaslıgil, Ü. (1995). Üstün Zekalı Çocukların Eğitimi. Yaşadıkça Eğitim, Kasım-Aralık, sayı 43.

Davaslıgil, Ü. (2004). Erken Çocuklukta Üstün Zekâlı Çocuklara Uygulanacak Farklılaştırılmış Eğitim Program. Şirin, M.R., Kulaksızoğlu A., \& Bilgili, A.E. (Eds.), I. Türkiye Üstün Yetenekli Çocuklar Kongresi Seçilmiş Makaleler Kitabı. Özel Eğitimin Tarihçesi Bölümü (15-37). İstanbul: Çocuk Vakfı Yayınları.

Dey, I. 1993, Qualitative Data Analysis: A User-Friendly Guide for Social Scientists, London: Routledge Publications

Ersoy, Ö. ve Avcı, N. (2004). Üstün Zekâlı ve Üstün Yetenekliler. Şirin, M.R., Kulaksızoğlu A., \& Bilgili, A.E. (Eds.), I. Türkiye Üstün Yetenekli Çocuklar Kongresi Seçilmiş Makaleler Kitabı Özel Eğitimin Tarihçesi Bölümü (15-37). İstanbul: Çocuk Vakfı Yayınları.

Gürbüz, S., \& Şahin, F. (2018). Sosyal Bilimlerde Araştırma Yöntemleri. Ankara: Seçkin Yayıncılık.

Kanlı, E. (2011). Üstun Zekalı Ve Yeteneklilerin Alan Eğitiminde Hızlandırma. Hasan Ali Yücel Eğitim Fakültesi Dergisi Sayı 16 (2011-2), 85-104.

Kaplan, A. (2008). Raven'ın İlerleyen Matrisler Plus Testinin 12-13 Yaş Çocukları Üzerinde Geçerlik, Güvenirlik Ve Ön Norm Çalışmalarına Göre Üstün Zekalı Olan Ve Olmayan Öğrencilerin Mantıksal Düşünme Yeteneklerinin Karşılaştırılması. Yüksek Lisans Tezi. İstanbul Üniversitesi Sosyal Bilimler Enstitüsü Özel Eğitim Anabilim Dalı Üstün Zekâlıların Eğitimi Bilim Dalı.

Kırkıç, K.A. (2019). A Study on the University Placement System for Gifted Children in Turkey. Journal of Education and Learning; Vol. 8, No. 3; 2019, doi:10.5539/jel.v8n3p59

Levent, F. (2011). Üstün Yetenekli Çocukların Hakları El Kitabı; Anne Baba Ve Öğretmenler İçin. 1. Türkiye Çocuk Hakları Kongresi .Çocuk Vakfı Yayınları, İstanbul. Yayın Dizisi:12 ss: 28

Marland, S. P., Jr. (1972). Education of the gifted and talented, Volume I: Report to the Congress of the United States by the Commissioner of Education. Washington, DC: United States Government Printing 
Office.

Mertkan, Ş. (2015). Karma araştırma tasarım. Ankara: Pegem-A Akademi.

MEB, (2006). 17. Milli Eğitim Şûrası. (13-17 Kasım 2006). Erişim Adresi: https://ttkb.meb.gov.tr/meb iys dosyalar/2017 09/29165619 17 sura.pdf

MEB. (2014). Milli Eğitim Bakanlığı. Özel Eğitim Ve Rehberlik Hizmetleri Genel Müdürlüğü. Özel Yetenekli Çocuklar Aile Kılavuzu. 10.09.2018 Erişim: http://orgm.meb.gov.tr/alt sayfalar/yayimlar/ozelegitim/ aile kilavuzu/aile kilavuzu.pdf

MEB. (2017). (ÖZEL EĞiTiM VE REHBERLIK HIZMETLERI GENEL MÜDÜRLÜĞÜ, "Ben Anlayın: ÖZEL YETENEKLI ÇOCUĞUM VAR" https://orgm.meb.gov.tr/meb iys dosyalar/2017 06/19122200 07143702 Aile EYitim KYlavuzu.pdf

Özbay, Y. (2013). Üstün Yetenekli Çocuklar ve Aileleri. T.C. Aile ve Sosyal Politikalar Bakanlığı Aile ve Toplum Hizmetleri Genel Müdürlüğü tarafından hazırlatılmış Aile Eğitim Programı. ISBN: 978-6054628-54-4. Hangar Baskı / ANKARA.

Şahin, F., \& Levent, F. (2015). Examining the methods and strategies which classroom teachers use in the education of gifted students. The Online Journal of New Horizons in Education, 3(5), 73-82.

Türkiye Cumhuriyeti Ölçme Seçme ve Yerleştirme Merkezi (ÖSYM), (2019). 2019-YKS Sınav Sonuçlarına İlişkin Sayısal Bilgiler. https://www.osym.gov.tr/TR,16859/2019-yks-sinav-sonuclarina-iliskin-sayisalbilgiler.html adresinden alınmıştır.

TÜBITAK, (2010). Üstün Yeteneklilerin Eğitimi Ortak Akıl Platformu (20-22 Aralık). https://orgm.meb.gov.tr/meb iys dosyalar/2013 08/27032244 2022 aralk uyoap.pdf

Yıldııım, A. \& Şimşek, H. (2008). Sosyal bilimlerde nitel araştırma yöntemleri. Ankara: Seçkin Yayıncılık.

Yin, R. K. (2014). Case Study Research Design and Methods (5th ed.). Thousand Oaks, CA: Sage. 